\title{
PEMANFAATAN TEKNOLOGI BARCODE PADA SISTEM INFORMASI PERPUSTAKAAN DI SMK MUHAMMADIYAH 3 PEKANBARU
}

\author{
Darmanta Sukrianto1, Dwi Oktarina ${ }^{2)}$ \\ 1.Akademi Manajemen Informatika dan Komputer "Mahaputra Riau" \\ 2.STIKOM Pelita Indonesia Pekanbaru \\ Email: 1.darman1407@gmail.com 2.dwi.oktarina@lecturer.pelitaindonesia.ac.id
}

\begin{abstract}
Libraries are places to develop information and knowledge managed by one educational institution or another. The development of the current library is closely related to the service, which in the service system must be good in processing the data information must be fast and accurate so as to launch the process of the library services. Barcode is a code that can be read by computer by using barcode technology to assist the process of searching and examining data automatically. The system for lending and processing of book data has not utilized computerized technology in the conventional sense of using book media so that often there are mistakes in member data collection, book searching, borrower's transactions, return and information either visually or in the form of report which is given not in accordance with the existence of problems it is necessary to use a computerized system utilizing barcode technology to facilitate the processing of data books and information so as to become more epektif and efficient.
\end{abstract}

Keywords: Library, Barcode Technology, Computers

\begin{abstract}
Abstrak. Perpustakaan adalah tempat untuk mengembangkan informasi dan pengetahuan yang dikelola oleh satu lembaga pendidikan atau lembaga lainnya. Perkembangan perpustakaan saat ini sangat erat kaitannya dengan pelayanan, yang mana dalam sistem pelayanan harus baik dalam mengolah informasi data harus cepat dan akurat sehingga melancarkan proses dari pelayanan perpustakaan tersebut. Barcode merupakan kode yang dapat dibaca oleh komputer dengan mengunakan teknologi barcode membantu proses pencarian dan pemeriksaan data secara otomatis. Sistem untuk peminjaman dan pengolahan data buku belum memanfaatkan teknologi komputerisasi dalam arti masih konvensional menggunakan media buku sehingga sering terjadi kesalahan pada pendataan anggota, pencarian buku, transakasi peminjama, pengembalian dan informasi baik secara visual maupun dalam bentuk laporan yang di berikan tidak sesuai dengan adanya permasalahan tersebut maka perlu adanya sistem menggunakan komputerisasi memanfaatkan teknologi barcode sehingga memudahkan pengolahan data buku dan informasi sehingga menjadi lebih epektif dan efisien.
\end{abstract}

Kata Kunci : Perpustakaan, Teknologi Barcode, Komputer 


\section{PENDAHULUAN}

Disaat sekarang ini perkembangan dunia teknologi sangat berkembang pesat, dimana semua instansi dituntut harus mengupayakan peranan teknologi dari berbagai segi, baik dari segi sumber daya manusia, pelayanan, yang mana dapat meningkatkan kualitas dari kerja yang dilakukan, dan didukung dengan adanya suatu sistem informasi yang akurat dalam penyajian informasinya.

Dalam meningkatkan pengetahuan peran dari perpustakaan sangat penting kebutuhannya, khususnya ditengah masyarakat karena perpustakaan dapat meningkatkan ilmu pengetahun masyarakat. Dalam pelayanannya yang luas maka, dengan memanfaatkan teknologi informasi diharapkan dapat memenuhi kebutuhan masyarakat dari segi pelayanan perpustakaan, sehingga dalam pengolahan datanya dilakukan dengan cepat dan akurat.

SMK Muhammadiyah 3 Terpadu merupakan salah satu jenjang pendidikan Sekolah Menengah Kejuruan (SMK) yang bertujuan mempersiapkan lulusannya untuk bisa langsung terjun kedunia kerja. Saaat ini fasilitas pada SMK Muhammadiyah 3 Terpadu sudah mengalami kemajuan : ada beberapa labor dan ruang perpustakaan. Adapun Aktifitas yang dilakukan pada perpustakaan SMK Muhammdiyah 3 terpadu seperti Pengolahan data, peminjaman maupun pengembalian, serta denda pengembalian buku. Proses pengolahan data perpustakaan SMK Muhammdiyah 3 masih dilakukan secara konvensional yaitu proses pencatatan data buku, anggota, data peminjam, data pengembalian, dan denda masih dilakukan pada buku besar. Yang dalam proses yang berjalan di perpustakaan tersebut yaitu setiap siswa yang akan meminjam buku ke perpustakaan tersebut dicatat oleh petugas perpustakaan yang mana dalam sekali minjam diberi tempo satu minggu. Jika dari siswa yang meminjam buku terlambat dalam pengembalian akan dikenakan denda dari setiap buku.
Dalam pengolahan data yang masih konvensional tentunya banyak kekurangan, misalkan dalam mencari data sipeminjam yang dilakukan mengecek satu persatu pada buku besar, serta dalam pengembalian buku juga dilakukan satu persatu pada buku besar, yang jika sewaktu waktu buku besar tersebut rusak atau hilang maka mengakibatkan permasalahan karena tidak adanya salinan dari data yang ada didalam buku besar tersebut.

Oleh karena itu perlu adanya suatu sistem informasi perpustakaan berbasis dekstop dengan menggunakan suatu bahasa pemograman dengan menggunakan alat Barcode, sehingga dapat mempermudah pekerjaan petugas dalam mengelola data peminjaman buku dan pengembalian buku perpustakaan, proses pencarian buku, pengolahan data anggota dan pelaporan kepala perpustakaan akan lebih efektif dan efisien.

\section{METODE PENELITIAN}

\subsection{Penelitian Lapangan (Observasi)}

Untuk mengetahui sistem yang sedang berjalan saat ini pada perpustakaan SMK Muhammdiyah 3 Terpadu, maka penulis langsung melakukan penelitian pada SMK Muhammdiyah 3 Terpadu.

\subsection{Wawancara (Interview)}

Metode ini digunakan untuk mendapatkan Informasi secara langsung dengan divisidivisi yang telah ditetapkan oleh SMK Muhammdiyah 3 Terpadu yang berhubungan dengan sistem. Pihak pihak yang diwawancari oleh penulis, sebagai berikut :

1. Kepala Sekolah SMK Muhammadiyah 3 Terpadu.

2. Kepala Perpustakaan SMK Muhammadiyah 3 Terpadu.

\subsection{Studi Pustaka}

Metode ini dilakukan untuk mendapatkan bahan referensi seperti buku-buku dan jurnal-jurnal yang berkaitan dengan topik penelitian dan dijadikan sebagai dasar perbandingan antara data yang penulis dapat dilapangan. 


\section{HASIL DAN PEMB AHASAN}

\subsection{Teori}

\section{Sistem}

Sistem adalah suatu urut- urutan operasi klerikal (tulis menulis), biasanya melibatkan beberapa orang atau satu atau lebih departemen, yang diterapkan untuk menjamin penanganan yang seragam dari transaksi-transaksi yang terjadi (Zefriyenni dan Santoso, 2015).

\section{Informasi}

Menurut Sutanta (2011:13) Informasi merupakan hasil pengolahan data sehingga menjadi bentuk yang penting bagi penerimanya dan mempunyai kegunaan sebagai dasar dalam pengambilan keputusan yang dapat dirasakan akibatnya secara langsung saat itu juga atau secara tidak langsung pada saat mendatang.

\section{Sistem Informasi}

Sistem informasi adalah serangkaian komponen berupa manusia, prosedur, data dan teknologi (komputer) yang digunakan untuk melakikan sebuah proses untuk menghasilkan informasi yang bernilai untuk pengambilan keputusan (Sugiyanto dkk, 2013).

\section{Data}

Menurut Sutanta (2011:13) Data merupakan bahan keterangan tentang kejadian-kejadian nyata atau fakta-fakta yang dirumuskan dalam sekelompok lambang tertentu yang tidak acak yang, yang menunjukan jumlah, tindakan atau hal. Data dapat berupa catatan-catatan dalam kertas, buku, atau tersimpan sebagai file dalam basis data. Data menjadi bahan dalam suatu proses pengolahan data.

\section{Perpustakaan}

Ada beberapa pengertian perpustakaan yaitu (Hendrianto dan Eko, 2014) :

1. Perpustakaan diartikan sebuah ruangan atau gedung yang digunakan untuk menyimpan buku dan terbitan lainnya yang biasanya disimpan menurut tata susunan tertentu yang digunakan pembaca bukan untuk dijual.

2. Dalam pengertian yang terbaru seperti yang tercantum dalam keputusan presiden RI nomor II disebut bahwa perpustakaan merupakan salah satu sarana pelestarian bahan pustaka sebagai teknologi dan kebudayaan dalam rangka mencerdaskan kehidupan bangsa dan menunjang pelaksanaan pembangunan nasional.

3. Menurut RUU Perpustakaan pada Bab 1 pasal 1 menyatakan Perpustakaan adalah institusi yang mengumpulakan pengetahuan tercetak dan terekan, mengelolanya dengan cara khusus guna memenuhi kebutuhan intektualitas para penggunanya melalui baragam cara interaksi pengerahuan.

\section{Sistem Informasi Perpustakaan}

Sistem Informasi Perpustakaan adalah suatu sistem di dalam suatu organisasi yang mempertemukan kebutuhan pengolahan data harian, penunjang kegiatan dalam penyimpanan data, dan menyediakan pihak luar tertentu dengan laporan-laporan yang diperlukan (Cahyaningtyas dkk, 2015) sedangkan menurut (SIPERPUS / 29 April 2009) Sistem Informasi Perpustakaan (SIPERPUS) merupakan perangkat lunak yang didesain khusus untuk mempermudah pendataan koleksi perpustakaan, katalog, data anggota / peminjam, transaksi dan sirkulasi koleksi perpustakaan.

\section{Aliran Sistem Informasi (ASI)}

Zefriyenni dan Santoso (2015) Aliran sistem informasi sangat berguna untuk mengetahui permasalahan yang ada pada suatu sistem. Dari sini dapat diketahui apakah sistem informasi tersebut masih layak dipakai atau tidak, masih manual atau komputerisasi. Jika sistem informasinya tidak layak lagi maka perlu adanya perubahan dalam pengolahan datanya sehingga menghasilkan informasi yang cepat dan akurat serta keputusan yang lebih baik. Berikut simbol-simbol dari Aliran Sistem Informasi (ASI) : 
Tabel 3.1 Simbol-Simbol Pada Aliran Sistem Informasi (ASI)

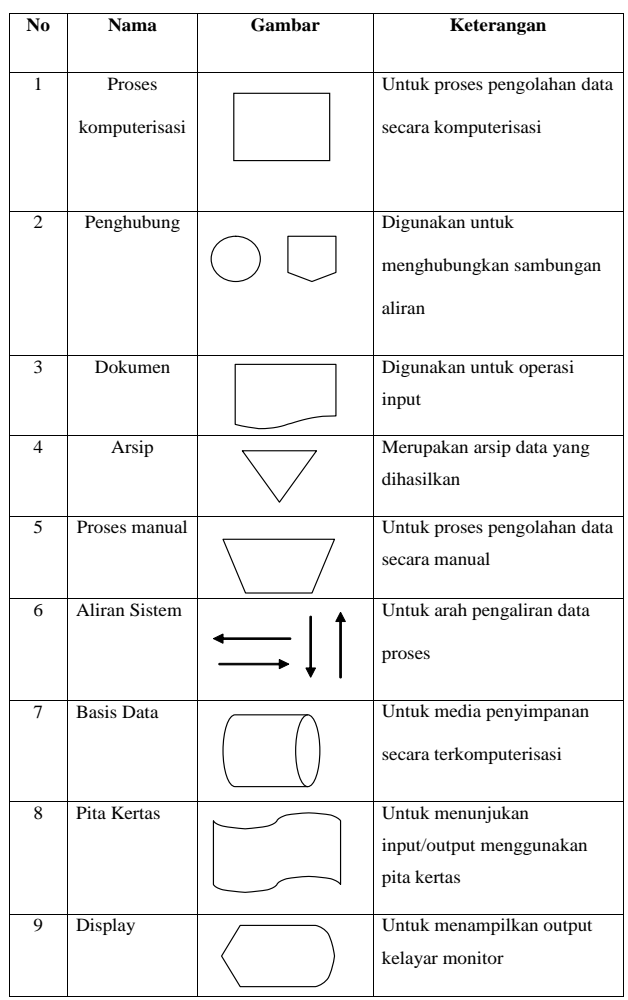

(Sumber Zefriyenni dan Santoso : 2015)

\section{Context Diagram}

Zefriyenni dan Santoso (2015) Context Diagram adalah gambaran umum tentang suatu sistem yang terdapat didalam suatu organisasi yang memperlihatkan batasan (boundary) sistem, adanya interaksi antara eksternal entity dengan suatu sistem dan informasi secara umum mengalir diantara entity dan sistem. Context Diagram merupakan alat bantu yang digunakan dalam menganalisa sistem yang akan dikembangkan.

Simbol-simbol yang digunakan di dalam Context Diagram hampir sama dengan simbol-simbol yang ada pada DFD, hanya saja pada Context Diagram tidak terdapat simbol file. Berikut simbol-simbol dari Contex Diagram :
Tabel 3.2 simbol-simbol dari Context Diagram (CD)

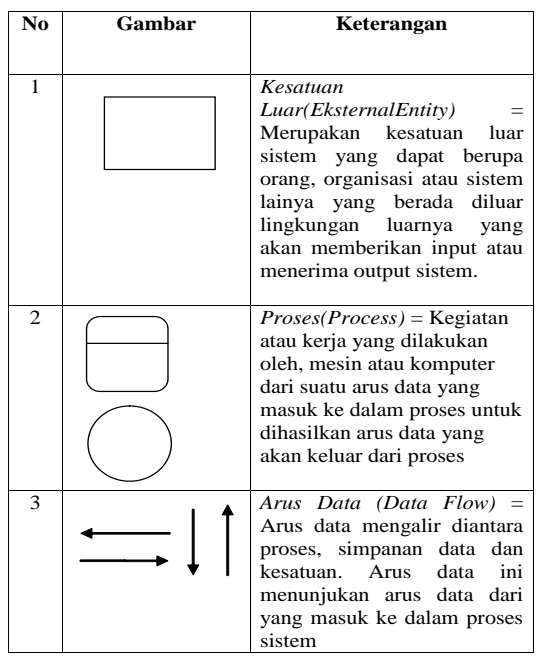

(Sumber Zefriyenni dan Santoso : 2015)

\section{Data Flow Diagram (DFD)}

Zefriyenni dan Santoso (2015) DFD merupakan gambaran sistem secara logika yang tidak tergantung pada perangkat keras, lunak, struktur data dan organisasi file. Keuntungan dari DFD adalah untuk memudahkan pemakai yang kurang menguasai bidang komputer untuk mengerti sistem yang akan dikerjakan atau dikembangkan. Berikut simbolsimbol dari Data Flow Diagram (DFD) :

Tabel 3.3 simbol-simbol dari Data Flow Diagram (DFD)

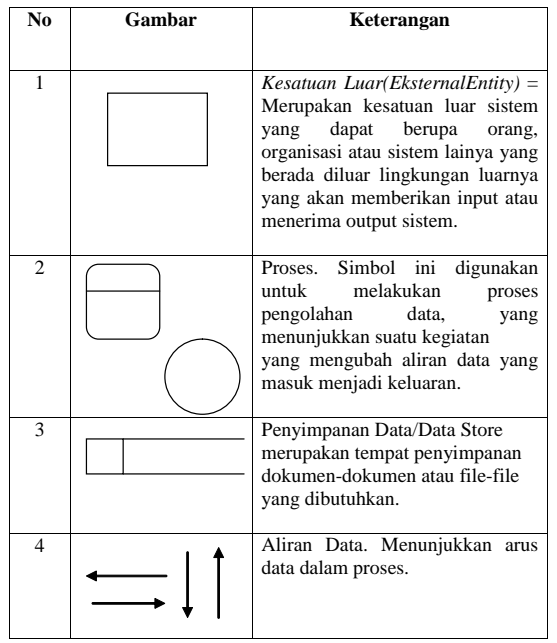

(Sumber Zefriyenni dan Santoso : 2015) 


\section{Entity Relationship Diagram (ERD)}

Model ERD berisi komponenkomponen entitas dan himpunan relasi yang masing-masing dilengkapi dengan atribut-atribut yang mempresentasikan seluruh fakta yang ditinjau sehingga dapat diketahui hubungan antara entity-entity yang ada dengan atribut-atributnya. Selain itu juga bisa menggambarkan hubungan yang ada dalam pengolahan data, seperti hubungan many to many, one to many, one to one. Berikut simbol-simbol dari ERD :

\section{Tabel 3.4 Simbol-Simbol Pada Entity Relationship Diagram (ERD)}

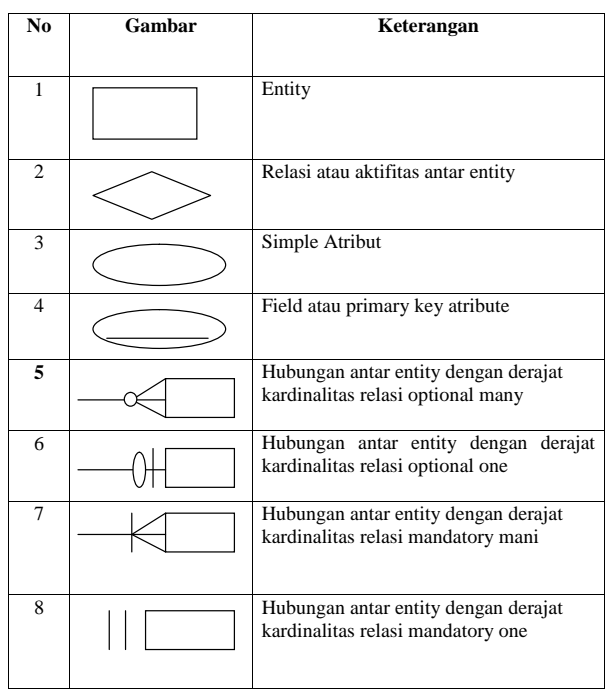

(Sumber Zefriyenni dan Santoso : 2015)

\section{Kode Batang (Barcode)}

Barcode atau kode batang adalah sekumpulan data yang digambarkan dengan garis dan jarak spasi (ruang). Barcode menggunakan urutan garis batang vertikal dan jarak antar garis untuk mewakili angka atau simbol lainnya. Dengan demikian, setiap ketebalan garis batang dan jarak antara garis saru dengan yang lain selalu berbeda sesuai dengan isi data yang dikandung oleh kode batang atau barcode tersebut. Terdapat beberapa standar kode dalam barcode sesuai dengan kegunaan dan tujuan pemakaian barcode, seperti pada daftar berikut :

1. Uniform Product Code (UPC) : untuk checkout penjualan, persediaan, dan sebagainya pada toko retail.
2. Code 39 (Code 3 of 9) : identifikasi, inventarisasi, dan pengiriman pelacakan.

3. POSTNET : kode pos encoding di US mail.

4. European Article Number (EAN) : sebuah superset dari UPC yang memungkinkan digit ekstra untuk identifikasi negara.

5. Japanese Article Number (JAN) : serupa dengan EAN, digunakan di Jepang.

6. Bookland : berdasarkan nomor ISBN dan digunakan pada sampul buku.

7. ISSN bar code : berdasarkan nomor ISSN, digunakan pada majalah di luar AS.

8. Code 128 : digunakan dalam preferensi untuk Code 39 karena lebih kompak.

9. Interleaved 2 of 5 : digunakan dalam industri pelayaran dan gudang.

10. Codabar : digunakan oleh Federal Express, di perpustakaan dan bank darah.

11. MICR (Magnetic Ink Character Recognition) : sebuah font khusus yang digunakan untuk nomor di bagian bawah cek bank.

12. OCR-A : format pengenalan karakter optik yang digunakan pada sampul buku, untuk nomor ISBN agar bisa dibaca oleh manusia.

13. OCR-B : digunakan untuk mempermudah pembacaan barcode versi UPC, EAN, JAN, Bookland, dan ISSN dan Code 39.

14. Maxicode : digunakan oleh United Parcel Service.

15. PDF417 : suatu jenis barcode 2-D baru yang dapat encode sampai 1108 byte informasi; dapat terkompresi seperti pada sebuah portabel file data (PDF).

16. RSS-Code: suatu jenis barcode yang sering digunakan pada bahan kemasan atau sering juga disebut Reduced Space Symbology yang dapat menyimpan lebih banyak data dalam setengah jumlah ruang dan menawarkan alternative untuk teknologi RFID.

Berikut ini contoh barcode jenis barcode Code 39 (Sovia, 2010) : 


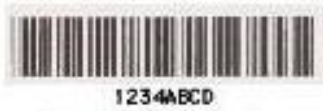

Gambar 3.1 Barcode jenis Code 39

\section{Barcode Reader}

Barcode reader adalah salah satu perangkat penting yang digunakan untuk memindai/menscan kode dari barcode itu sendiri. Bentuk dari Barcode reader sendiri bermacam-macam tergantung dari kebutuhan penggunanya.

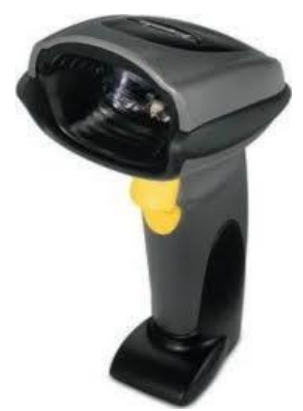

Gambar 3.2 Barcode Reader

Menurut Arfida dkk (2014) Barcode merupakan metode yang efektif untuk mengidentifikasikan dan memasukkan informasi ke dalam sebuah komputer". Barcode terdiri dari sejumlah baris dan spasi (hitam dan putih) dalam rasio yang didefinisikan yang mempresentasikan suatu karakter tertentu. Pada umumnya, struktur dari suatu barcode diawali dengan sebuah karakter mulai yang menandakan permulaan pengkodean barcode. Umumnya, setiap metode barcode mempunyai karakter mulai berbeda-beda, sehingga untuk mengetahui metode barcode yang dibuat dapat dilihat dari karakter mulainya. Karakter stop menandakan akhir pengkodean barcode.

Barcode digunakan untuk memudahkan indentifikasi berbagai hal, khususnya tentang produk dalam berbagai transaksi. Apabila jumlah produksi masal, akan sangat sulit jika sistem barcode tidak dipergunakan dalam pengindentifikasian suatu barang.

\subsection{Implementasi Sistem}

Hasil implementasi antar muka aplikasi sistem informasi perpustakaan SMK Muhammadiyah 3 sebagai berikut :

1. Menu Login

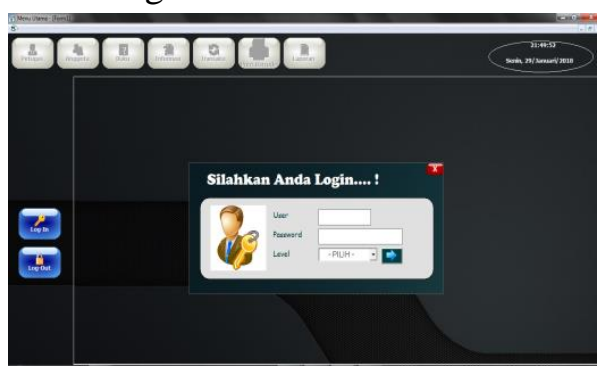

Gambar 3.3 Menu Login

Menu login merupakan form yang digunakan oleh user/petugas untuk mengakses program. Yang mana memiliki username, password dan userlevel sebagai keamanan. Pada menu ini yakni username anda harus memasukan nama sesuai dengan nama yang ada didatabase, kemudian pada password, userlevel juga demikian sehingga apabila anda ingin login tetapi data yang anda masukan tidak sesuai maka program tidak akan terbuka/tidak bisa login.

2. Menu Utama

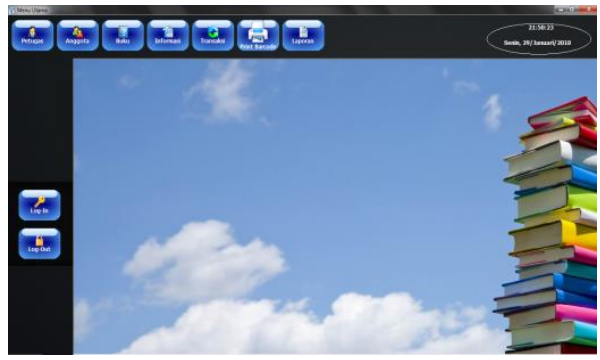

Gambar 3.3 Menu Utama

Menu utama merupakan tampilan awal dari program setelah user login yang mana pada menu ini menampilkan keseluruhan menu yang ada pada program tersebut. Sehingga dengan adanya menu utama ini akan memudahkan user/petugas dalam mengoperasikan program ini. 
3. Form Data Anggota

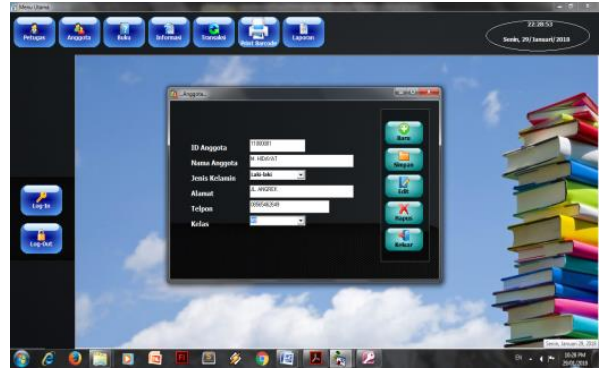

Gambar 3.4 Form Data Anggota

Form Data Anggota merupakan form yang dapat digunakan untuk menambah, menyimpan dan menghapus data anggota.

4. Form Info Data Anggota

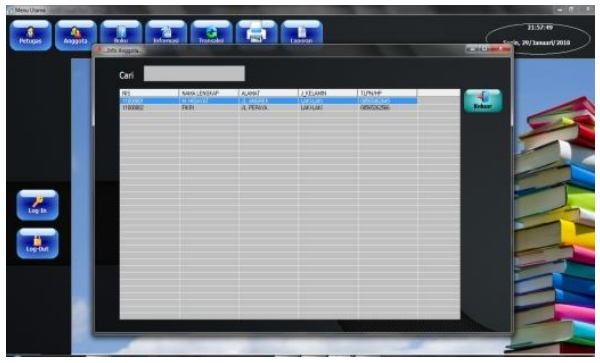

Gambar 3.5 Form Info

Form info data anggota merupakan form yang dapat digunakan untuk melihat view data anggota dan untuk pencarian data anggota.

5. Form Print/Cetak Barcode

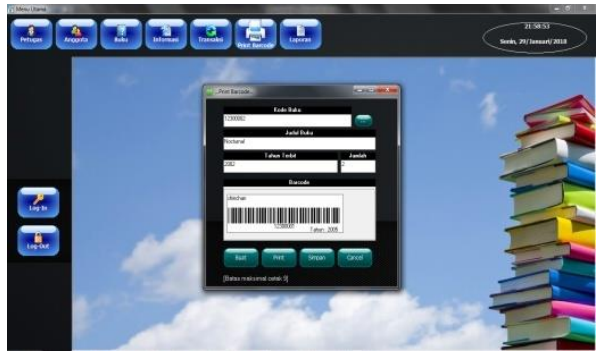

Gambar 3.6 Print/Cetak Barcode

Form Print Barcode ini digunakan untuk memproses dan mencetak kode barcode pada buku tersebut. Yang mana form ini digunakan untuk mencetak barcode buku yang belum memiliki barcode.

6. View Kertas Barcode

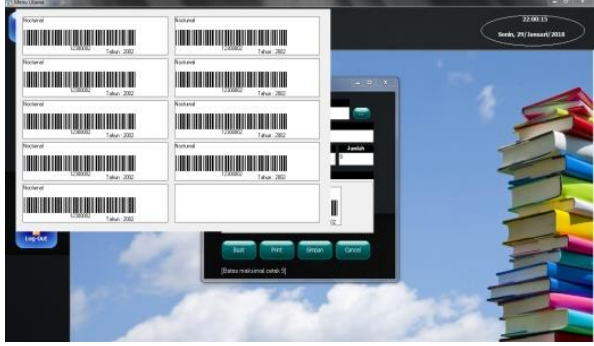

Gambar 3.7 Kertas Barcode

Kertas barcode ini digunakan untuk memproses pencetakan barcode yang nantinya kartu hasil cetakan akan ditempelkan di buku dan akan di Scan menggunakan alat barcode.

7. Form Peminjaman

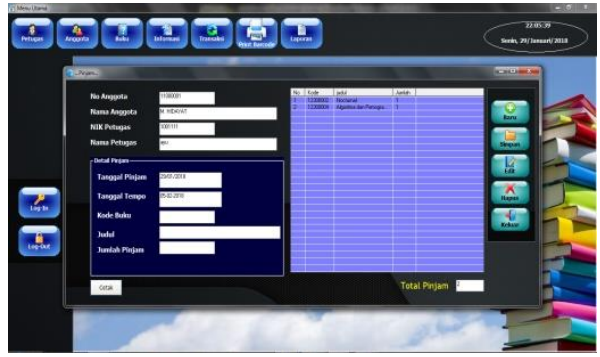

Gambar 3.8 Form Peminjaman

Form Transaksi peminjaman digunakan untuk memproses peminjaman buku pada perpustakaan dengan form ini dapat mempermudah proses transaksi peminjaman buku.

8. Form Pengembalian

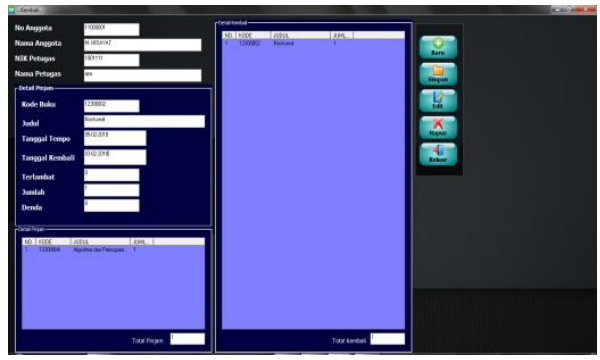

Gambar 3.9 Form Pengembalian

Form transaksi pengembalian digunakan untuk memproses pengembalian buku. Dengan adanya sistem ini dapat membantu kinerja dari petugas dalam mengolah data pengembalian buku. 


\section{SIMPULAN}

Dari penelitian yang dilakukan kesimpulan yang dapat diambil dari pembahasan bab-bab sebelumnya yaitu :

1. Sistem Informasi yang berjalan masih banyak melakukan pencatatan menggunakan kertas yang mengakibatkan mudah terjadi nya buku hilang dan tidak adanya kerapian. Sistem informasi pengelolaan data, peminjaman, pengembalian dan denda pengembalian buku masih melakukan cara konvensional yang mengakibatkan mudah terjadi nya buku hilang dan tidak adanya kerapian. Lambatnya pembuatan laporan-laporan dan tidak diarsipkan sehingga ketika kepala perpustakaaan membutuhkan laporan tersebut admin harus membuat dari awal dan ini akan membutuhkan waktu yang lama dicatat dikertas.

2. Sistem baru pada Perpustakaan SMK Muhammdiyah 3 dengan memanfaatkan barcode dapat meningkatkan efektifitas dan efesiensi sistem sehingga diperoleh informasi secara cepat, tepat dan akurat. Sistem Informasi Perpustakaan ini juga dapat dijadikan alternative untuk mempermudah proses pengolahan data Perpustakaan dan proses pelaporan dapat dilakukan dengan cepat, tepat dan efisien.

\section{DAFTAR PUSTAKA}

Zefriyenni, Budi Santoso. 2015. Sistem Informasi dan pengendalian Persediaan Barang Menggunakan Metode Economic Order Quantity (EOQ) Menggunakan Bahasa Pemrograman Java dan Database MYSQL pada Toko Kansa Elpiji. Jurnal KomTekInfo Fakultas Ilmu Komputer. Vol: 2, No. 2.
Sutanta, Edhy. 2011. Basis Data dalam Tinjauan Konseptual. Yogyakarta: ANDI.

Sugianto dkk. 2013. Sistem Informasi Penjualan pada Butik Luwes Fashion Kecamatan Tulakan.

Hendrianto, Dani Eko. 2014. Pembuatan Sistem Informasi Perpustakaan Berbasis Website pada Sekolah Menengah Pertama Negeri 1 Donorojo Kabupaten Pacitan. Vol: 3, No. 4.

Cahyaningtyas, Rosita, Siska Iriyani. 2015. Perancangan Sistem Informasi Perpustakaan pada Smp Negeri 3 Tulakan, Kecamatan Tulakan Kabupaten Pacitan. Vol: 4, No 2.

Arfida, Septilia, Rahman E. Harahap. 2014. Implementasi Media Pembelajaran Teknik Pengkodean Barcode Berbasis Multimedia dalam Meningkatkan Kualitas Kegiatan Belajar Mengajar. 